\title{
Peran Lembaga Konsultasi dalam Merubah Sikap dan Persepsi Istri Korban Dampak Kekerasan dalam Rumah Tangga di Sambas Perspektif Hukum Islam dan Hukum Positif
}

\author{
Tamrin $^{1 *}$, Sardjana Orba Manullang ${ }^{2}$, Gunawan Widjaja ${ }^{2}$, Hotmaria H. Sijabat ${ }^{3}$ \\ ${ }^{1}$ IAI Sultan Muhammad Syafiuddin Sambas, Indonesia \\ ${ }^{2}$ Universitas Krisnadwipayana Jakarta, Indonesia \\ ${ }^{3}$ Universitas 17 Agustus 1945 Jakarta, Indonesia
}

\begin{abstract}
Abstrak: Penelitian ini bertujuan untuk mengetahui bagaimana peran lembaga konsultasi dalam merubah sikap dan persepsi istri korban dampak kekerasan dalam rumah tangga (KDRT). Metode penelitian yang digunakan adalah penelitian empiris dengan bertitik tolak pada pendekatan analitis deskriptif untuk mendapatkan data tersebut dengan pengamatan dan wawancara. Penelitian ini menemukan bahwa sikap istri korban kekerasan dalam rumah tangga (KDRT) selalu menutup diri dikarenakan tindakan tersebut aib keluarga dan berpersepsi perbuatan pelaku semata-mata kehilafan. Oleh karena itu peran lembaga konsultasi dan bantuan hukum (LKBH) Sambas sangat penting dalam menggali informasi dari korban terkait fakta lapangan melalui pendekatan komunikatif dan persuasif, serta nilai kemaslahatan yang tertuang pada Al-Qur'an.
\end{abstract}

Kata Kunci: lembaga konsultasi, kekerasan dalam rumah tangga, hukum Islam, hukum positif

\begin{abstract}
This study aims to determine how the role of consulting institutions in changing attitudes and perceptions of wives of victims of domestic violence (KDRT). The research method used is empirical research with a starting point of a descriptive analytical approach to obtain the data by observation and interviews. This study found that the attitude of the wife of the victim of domestic violence (KDRT) always closes herself because the action is a family disgrace and the perception that the perpetrator's act is simply an error. Therefore the role of the Sambas consultation and legal aid institution $(\mathrm{LKBH})$ is very important in extracting information from victims related to facts on the ground through communicative and persuasive approaches, as well as the value of benefit contained in the Al-Qur'an.
\end{abstract}

Keywords: consultancy agencies, domestic violence, Islamic law, positive law

\section{Pendahuluan}

Membangun rumah tangga (RT) merupakan bentuk kasih sayang sepasang manusia yang diwujudkan dalam ikatan sakral sebuah pernikahan. Masing-masing kedua mempelai, sanak famili, dan tetangga ikut memberikan selamat serta doa kepada pasangan mempelai yang sedang melangsungkan pernikahan. Sakinah, mawaddah, warahmah (samawa) merupakan sebuah doa yang lumrah diterima oleh pengantin. Namun, suatu keadaan yang tidak diinginkan sebagai ancaman terhadap nilai-nilai moral di masyarakat bisa terjadi dalam ruang lingkup RT (Rahaman, 2011). Tindakan kekerasan dalam rumah tangga (KDRT), lazimnya

\footnotetext{
* Corresponding Author: Tamrin (tamrinmuchsin69@gmail.com). IAI Sultan Muhammad Syafiuddin Sambas, Indonesia
}

ISSN 1412-1697 (Print); ISSN 2477-3816 (Online) 
antara pelaku dan korban yang merupakan anggota keluarga di dalam RT.

Permasalahan sosial pada ruang lingkup RT adalah tindak kekerasan pada istri. Masalah sosial timbul dari kekurangan individu yang bersumber pada faktor ekonomi, kebudayaan dan lain-lain serta merupakan pelanggaran norma-norma moral dalam masyarakat (Nasution, 2004). Kekerasan pada konteks RT kebanyakan dilakukan seorang suami seperti memukul atau menampar istri dan melontarkan lisan yang tidak etis ialah bentuk diskriminasi. Diskrminasi terhadap perempuan dapat diartikan sebagai suatu hal yang mengucilkan, membedakan atau melakukan pembatasan atas dasar jenis kelamin dengan tujuan untuk menghalangi, meniadakan pengakuan terhadap dinikmatinya HAM dan kebebasan dasar oleh kaum perempuan (Margaret A dan Thomas (Penyunting), 2001; Kania, 2015).

Kultur budaya yang berkembang dimasyarakat, pada konteks pasangan suami-istri pada umumnya mengedepankan suami daripada posisi istri. Yang mana kultur budaya ini harus dibenahi pada tatanan hukum di Indonesia, dan tentunya menjadi perhatian serius karena ini bicara kehidupan hukum dan perilaku bangsa, termasuk didalamnya pembinaan individu dan sosial (Warassih, 2005). Sebagai bentuk sarana pencegahan tindakan KDRT agar tidak secara masif dilakukan terus menerus, dengan diundangkannya suatu legislasi hukum pada tatanan sistem hukum di Indonesia merupakan salah satu harapan untuk dapat meminimalisir masalah tindak KDRT terhadap istri (Margaret A dan Thomas (Penyunting), 2001). Berlakunya Undang-Undang Penghapusan KDRT Nomor 23 Tahun 2004 mendefinisikan secara yuridis mengenai KDRT adalah semua perbuatan terhadap orang lain terutama perempuan, yang mengakibatkan kesengsaraan atau penderitaan baik fisik, seksual, psikologis atau menelantarkan rumah tangga termasuk mengancam untuk melakukan suatu perbuatan, pemaksaan, atau perampasan kemerdekaan dengan melawan hukum dalam lingkungan rumah tangga.

Pemberlakuan

Undang-Undang Penghapusan KDRT dapat dimaknai sebagai proses jerih payah kaum perempuan yang berbuah keberhasilan dalam upaya mengentas kekerasan terhadap perempuan yang dilatarbelakangi gender. Pada perspektif islam bahwa perilaku KDRT bukanlah bersumber dari ajaran agama, karena pada dasarnya sebuah pernikahan dibangun dengan kasih sayang (Zulkifli, 2019). Pendapat Mansour Fakih yang notabene merupakan pendamping masyarakat khusus pelatihan dan konsultasi gender, mendefinisikan kekerasan itu berbentuk hantaman yang menyerang fisik ataupun mental orang lain yang menjadi sasarannya (Samadani, 2013).

Bentuk tindak kekerasan pada istri terdiri atas kekerasan pada jasmani, psikis, ekonomi, serta tekanan seksualitas. Pada deklarasi Perserikatan Bangsa-Bangsa (PBB) yang disebut sebagai kekerasan pada istri dirumuskan yaitu segenap wujud tindakan yang mengakibatkan tekanan jasmani psikis dan seksualitas termasuk juga tindakan intimidasi terhadap hak-hak kemerdekaan kaum perempuan secara semena-mena baik peristiwa yang terjadi di ruang publik maupun kehidupan privat/keluarga, bermotifkan perbedaan jenis kelamin (Nofiardi, 2016; Lihat juga Deklarasi PBB Tentang Penghapusan Tindak Kekerasan Terhadap Perempuan Pasal 1).

Berdasarkan hasil obsevasi peneliti pda 6 Januari 2020 di Kantor Polres Sambas, data KDRT menunjukan bahwa pada tahun 2017 terdapat 13 kasus, tahun 2018 berjumlah 10 kasus dan tahun 2019 berjumlah 7 kasus. Berdasarkan data di atas, menunjukan bahwa secara kuantitatif kasus KDRT 
menunjukan penurunan pada tiap tahunnya. Tetapi secara realitas semakin meningkat KDRT di Sambas, belum lagi jika menggunakan pendekatan Iceberg Theory yang dicetuskan oleh Ernest Hemingway, yang mana data yang diperoleh hanyalah gambaran permukaan yang jauh lebih besar yang tidak atau belum terungkap ke permukaan (Zulkifli, 2019; Lihat juga Iceberg Theory). Secara umum, tidak terungkapnya tindakan KDRT disebabkan karena istri korban KDRT cenderung mengambil sikap diam untuk mempertahankan nilai-nilai keharmonisan keluarga dan itri beranggapan bahwa kekerasan yang dilakukan suami disebabkan kekhalifan sesaat.

Peran Lembaga Konsultasi, salah satunya Lembaga Konsultasi dan Bantuan Hukum (LKBH) yang merupakan model Studi Yale dengan pendekatan komunikatif dan persuasif, untuk strategi pengubahan sikap lewat komunkasi (Azwar, 1988; Zuchdi, 1995). Sikap sosial berupa komunikasi terbentuk oleh adanya interaksi sosial. Manusia disebut makhluk sosial sebab tidak bisa terlepas dari interaksi antar sesama manusia. Di dalam interaksi tersebut, tentunya sebagai makhluk yang berdiri secara mandiri, manusia memiliki pola yang beragam sesuai dengan keinginan masingmasing individu (Soekanto, 2007).

Menurut David Korten, MM Billah, (Saidi, 1995; Budairi, 2002) menyatakan bahwa lembaga konsultasi atau Lembaga Swadaya Masyarakat (LSM) merupakan salah satu upaya mengatasi persoalan masyarakat, pengembangan masyarakat dan organ yang terintegrasi dengan Pemerintah, serta menjadi perantara Pemerintah dengan masyarakat. Dalam Undang-Undang (UU) Penghapusan KDRT Pasal 14 secara eksplisit mengatur penyelenggaraan pelayanan terhadap korban dilakukan melalui koordinasi dengan berbagai pihak pada konteks ini yaitu: pihak pemerintah selaku pemangku kebijakan yang bekerjasama dengan lembaga sosial atau masyarakat umum.

\section{Metode}

Metode penelitian menggunakan yaitu metode empiris, (Waluyo 2002) dengan lokasi penelitian di Kabupaten Sambas, penelitian ini bersifat analitis guna mendeskripsikan suatu studi ilmiah yang bermaksud menginterprestasikan suatu kejadian pada konteks sosial secara alamiah dengan memprioritaskan cara kolerasi-korespodensi yang lebih rinci antara peneliti dengan keadaan yang diteliti (Herdiyansyah, 2012). Penelitian ini tetap memanfaatkan data statistik laporan kasus KDRT dari Polres Sambas. Data primer penelitian ini yaitu Lembaga Konsultasi, istri korban KDRT. Peneliti menggunakan purposive sampling dalam menentukan sampel pada sumber data. Penarikan sampel ini berlandaskan pada maksud penelitian yang akan dicapai (Mudzhar, 1998). Data sekunder menggunakan sumber hukum Islam, UU Penghapusan KDRT, Peraturan Daerah (Perda) tentang Lembaga Bantuan Hukum, buku, jurnal dan variabel-variabel lainnya yang relevan. Peneliti melakukan peninjauan dilapangan dan menulis dengan sistematis terhadap fenomena yang diteliti, hal ini yang digunakan dalam rangka teknik pengumpulan data (Arikunto, Suhardjono, dan Supardi, 2012). Selanjutnya, melakukan wawancara mendalam kepada Lembaga Konsultasi dan Istri korban KDRT di Kabupaten Sambas.

\section{Hasil Penelitian dan Pembahasan}

\section{Sikap dan Persepsi Istri Korban Dampak KDRT di Sambas}

Persoalan tindakan KDRT bukan persoalan yang baru terjadi, malahan persoalan ini seiring waktu tak kunjung menemui titik ujung serta jumlah tindakan ini mengalami peningkatan. Tentu 
dalam upaya penyelesaian perkara tindakan KDRT bukan hal yang gampang, terlepas dari aturan hukum positif yang mengatur bahwa tindakan tersebut merupakan delik aduan pada perkara tindak pidana. Artinya harus ada pengaduan terlebih dahulu oleh korban tindakan KDRT setelah itu, baru bisa diproses oleh aparat penegak hukum. Tentunya melihat aturan hukum positif seperti ini, korban biasanya enggan untuk melakukan pengaduan kepada penegak hukum dikarenakan mainset yang keliru seperti tindakan KDRT itu disebut sebagai aib keluarga. Berdasarkan hasil observasi peneliti yang didapat dari Pengadilan Negeri Sambas, data statistik menunjukan jumlah kasus KDRT yang tercatat di Pengadilan Negeri Sambas dan sudah inkracht van gewijsde berjumlah 9 kasus di tahun 2017, berjumlah 6 kasus di tahun 2018 dan berjumlah 2 kasus di tahun 2019.

Kasat Reskrim Polres Sambas, mengatakan penurunan jumlah kasus tindak pidana KDRT di Pengadilan Negeri Sambas ini bukan karena berkurangnya kasus atau pelaporan dari korban, bisa saja di sebabkan karena korban lebih memilih sikap untuk diam dan meredam tindakan KDRT ini supaya tidak diketahui oleh publik karena sudut pandang lain beranggapan ini merupakan sebuah aib keluarga. Menurut teori tindakan beralasan, yang dikemukakan Fishbein dan Ajzen (Siregar, 1992; Fishbein dan Ajzan, 1973; Zuchdi, 1995) mengatakan bahwa individu bergerak melakukan suatu tindakan berlandaskan maksud. Hal ini menjelaskan bahwa posisi variabel maksud berada diantara variabel sikap dan variabel perilaku. Teori ini mengatakan bahwa tindakan setiap individu berada pada variabel sikap yang pada posisi sentral. Jika individu beranggapan suatu tindakan yang dilakukan memiliki nilai positif, maka individu tersebut condong melakukan tindakan tersebut. Begitu sebaliknya, jika tindakan itu bernilai negative, maka ia condong mengabaikan tindakan tersebut.

Berkenaan dengan jenis KDRT yang dilaporkan oleh istri korban, berdasarkan hasil pengamatan dan data statistik yang didapat pada Polres Sambas, menunjukan bahwa tahun 2017 terdapat 13 perkara yang terdiri dari 10 perkara yang tergolong pada kekerasan fisik. 1 perkara yang tergolong kekerasan psikis, dan 2 perkara yang merupakan penelantaran keluarga. Tahun 2018 berjumlah 10 perkara yang terdiri atas: 6 perkara jenis kekerasan fisik, 2 perkara jenis kekerasan psikis, dan 2 perkara penelantaran keluarga. Pada tahun 2019 jumlah perkara sebanyak 7 perkara terdiri atas: 5 perkara merupakan kekerasan fisik, dan 2 perkara merupakan kekerasan psikis. Dari data diatas, Landi (Subbid Pidsus) juga mengutarakan pada jenis kekerasan yang tergolong penelantaran keluarga bisa diselesaikan dengan restorative justice, sedangkan pada jenis kekerasan fisik dan psikis, istri korban melaporkan kepada pihak kepolisian dengan motif untuk membuat jera suami/pelaku, yang notabene tidak sedikit berujung pada laporan kasus KDRT dicabut oleh korban. Meskipun ada juga kasus ini berujung pada putusan pengadilan. Persepsi istri korban yang menyebutkan bahwa tindakan melaporkan perbuatan kekerasan oleh suami dilandasi dengan alibi ingin membuat jera suami. Persepsi istri seperti ini, menurut Azwar (Azwar, 1988) ialah komponen kognitif dari struktur sikap. Komponen ini merupakan bagian dari 3 komponen yang terdapat pada struktur sikap yaitu: pertama kognitif, kedua afektif dan yang ketiga konatif. Komponen yang pertama ini berisikan persepsi dan kepercayaan mengenai objek sikap yang berbentuk suatu pandangan (Zuchdi, 1995).

Menurut Dw, Ay, Pt, My, Bc, Zm, N (nama inisial korban) berdasarkan hasil wawancara peneliti mengatakan bahwa korban mengetahui 
bentuk dan jenis KDRT melalui kabar berita dari media massa sebagai sarana informasi. Dalam merespon berbagai informasi dibutuhhkan sikap kritis. Memiliki pola pikir kritis inilah akan membentuk kepribadian yang kuat dan mampu melindungi diri dengan lisan yang berdasar. Selain itu, aspek pendidikan dan agama menjadi pemicu pengetahuan seorang individu. Kolerasi pendidikan dan agama menghasilkan sikap positif terhadap nilai-nilai yang dikonversi dalam hati dan akal.

Selanjutnya peneliti mencoba menggambarkan sikap istri korban dalam mengatasi masalah kekerasan pada ruang lingkup rumah tangga, hasil observasi pada 7 responden (korban KDRT) memperlihatkan sebanyak 5 responden mengatakan belum mampu mengatasi permasalahan sosial ini, korban lebih memilih menutup masalahnya dari keluarga maupun orang terdekat, yang disebabkan oleh faktor rasa malu yang notabene hal ini merupakan aib keluarga, atau lebih memikirkan kepentingan anak sehingga mengesampingkan dampak psikis atau jasmani yang dialami oleh korban, serta keinginan untuk terus bersama dengan pelaku karena rasa kecintaan yang lebih dominan. Sedangkan 2 responden lainnya mengatakan mampu mengatasi masalah dengan baik pada ruang lingkup rumah tangga, sikap baik ditunjukan dengan mampu mengenali sifat pasangan. Sikap mampu mengenali sifat pasangan yang akan menimbulkan pemicu terjadinya kekerasan pada ruang lingkup RT sangat diperlukan, sehingga dapat meredam tindakan kekerasan dapat disebabkan oleh pelaku (Soeroso, 2010).

\section{Peran Lembaga Konsultasi Dalam Merubah Sikap dan Persepsi Korban KDRT di Sambas Perspektif Hukum Positif}

Menjadi sebuah keinginan bagi setiap pasangan suami istri dalam berumah tangga yang dipenuhi rasa kerukunan sehingga yang dirasakan kehidupan menjadi bahagia, aman, tentram dan damai. Negara Republik Indonesia berdasarkan Ketuhanan Yang Maha Esa dijamin oleh Pasal 29 ayat (1) UUD Negara RI Tahun 1945. Artinya, setiap warga negara Indonesia (termasuk juga ruang lingkup keluarga) pada konteks menjalankan hak dan kewajiban dilandasi dengan nilai-nilai keagamaan. Hal ini menjadi acuan dalam menumbuh kembangkan pondasi yang kuat dan utuh membangun RT. Hukum positif di Indonesia menjelaskan perkawinan untuk membina keluarga sejahtera, bahagia dan abadi dalam ikatan sakral keagamaan, hal seperti ini lah sebenarnya yang menjadi tujuan pernikahan itu. Untuk mewujudkan tujuan dari pernikahan itu sendiri sangat dipengaruhi oleh faktor person atau individu pada lingkup RT, terutama pada cakupan tingkat kualitas perilaku dalam mengambil sikap serta pengendalian diri pada masing-masing individu.

Namun pada kenyataannya, untuk mencapai tujuan pernikahan tidak dengan mudah, dan waktu yang singkat untuk mewujudkannya. Tindakan KDRT bisa saja terjadi, terutama yang menjadi korban kekerasan adalah istri. Agar tindakan KDRT tidak terjadi, dilakukanlah upaya preventif, memberi perlindungan pada korban bahkan sampai penanganan pada pelaku KDRT, salah satunya dengan adanya kehadiran peran negara pada konteks ini dapat berupa lembaga sosial dan masyarakat wajib ikut andil mengambil peran tersebut dengan dasar falsafah Pancasila dan UUD Negara RI Tahun 1945. UU PKDRT secara eksplisit mengatakan dalam Pasal 10 bicara mengenai hak-hak korban untuk di lindungi oleh lembaga sosial dan pendampingan bantuan hukum pada tiap tahapan pemeriksaan mulai dari penyidikan sampai putusan pengadilan sebagaimana diatur dalam peraturan perundangundangan. 
Lembaga Konsultasi dan Bantuan Hukum (LKBH) Sambas merupakan salahsatu wahana pendampingan termasuk juga tindakan konsultasi dalam rangka merubah sikap dan persepsi istri korban KDRT. Hal ini senada dengan produk hukum di Kabupaten Sambas yang memberlakukan Perda Sambas No. 11 tahun 2015 Tentang Penyelenggaraan Bantuan Hukum, yang mana LKBH Sambas memberikan kegiatan konsultasi hukum, mediasi, negosiasi, dan pemberdayaan masyarakat. Berdasarkan hasil wawancara peneliti dengan Tamrin (ketua LKBH Sambas) mengungkapkan kegiatan konsultasi terhadap istri korban KDRT merupakan bagian dari upaya pemberdayaan masyarakat. Menurut Suharto, (Hatu, 2010; Suharto, 2006), Ife (Ife, 1995; Hatu, 2010) mengatakan pemberdayaan masyarakat meliputi aspek pemungkinan disini dimaknai dengan aspek langkah kemungkinan yang akan ditempuh dan gambaran yang akan terjadi, penguatan kepada klien untuk membuat sebuah keputusan, perlindungan terhadap pernyataan korban dan pemeliharaan kemampuan pengselarasan ide atau gagasan.

Pada konteks merubah sikap dan persepsi korban, hasil wawancara dengan Ketua LKBH Sambas mengutarakan bahwa objek perubahan itu berangkat dari pengalaman pribadi yang bersentuhan dengan dampak psikologis, kebudayaan, orang yang memiliki pengaruh yang penting bagi korban, lembaga pendidikan dan nilainilai keagamaan. Perubahan sikap dan persepsi dapat terjadi apabila interkasi bersifat persuasif dipahami dan diterima oleh korban (Zuchdi, 1995).

Peran yang dilakukan LKBH Sambas senada dengan hasil studi Hovland, (Azwar, 1988; Zuchdi, 1995) mengungkap strategi merubah sikap dan persepsi, akan disajikan dalam tabel berikut:
Tabel 1. Strategi Komunikasi dan Persuasi menurut Yale Model of Persuasion

\begin{tabular}{|c|c|c|}
\hline Faktor Sumber & $\begin{array}{c}\text { Perantara } \\
\text { Internal }\end{array}$ & $\begin{array}{l}\text { Perubaha } \\
\text { n Sikap }\end{array}$ \\
\hline $\begin{array}{l}\text { Keahlian dapat } \\
\text { dipercaya pendapatnya }\end{array}$ & Perhatian & Perubahan \\
\hline $\begin{array}{l}\text { Tipe daya pikat dan } \\
\text { argument } \\
\text { Persepsi } \\
\text { Kesimpulan } \\
\text { implisit/eksplisit }\end{array}$ & Pemahaman & $\begin{array}{l}\text { Perubahan } \\
\text { Dan Afeksi }\end{array}$ \\
\hline $\begin{array}{l}\text { Kemudahan dibujuk, } \\
\text { sikap tindakan semula }\end{array}$ & Penerimaan & Perubahan \\
\hline
\end{tabular}

\section{Peran Lembaga Konsultasi Dalam Merubah Sikap dan Persepsi Korban KDRT di Sambas Perspektif Hukum Islam}

Upaya LKBH Sambas dalam rangka mewujudkan sesuatu yang bermanfaat dan berguna bagi khalayak ramai, tentunya memberikan peran dan wadah tersendiri bagi korban tindakan KDRT yang berlandaskan kemaslahatan (Ali Yafie, 1994). Adapun penanganan yang dilakukan LKBH Sambas meliputi, upaya pencegahan, dan layanan pemberian perlindungan.

Pada perspektif hukum islam, upaya pencegahan terbagi menjadi 2 macam yaitu bentuk konseling, dan bentuk penyuluhan pada tindak KDRT. Upaya pencegahan bentuk konseling dan penyuluhan sebetulnya merupakan tahapan bertukar pikiran terhadap individu dalam menjalankan kehidupan berumah tangga agar tujuan pernikahan dapat tercapai atau dengan sebutan lain Samawa sebagaimana dalam firman Allah surat ar-Rum ayat 21. Hal ini telah diatur dalam firman Allah Surat al-Baqarah ayat 201 yang menjelaskan permohonan kebaikan di dunia dan akgir serta dipelihara dari siksa api neraka.

Konsep layanan pemberian perlindungan bagi korban KDRT oleh LKBH Sambas dengan jalur konsultasi dalam upaya membantu mediasi antara korban dan pelaku, serta upaya pemantauan 
dan pengawasan melalui pihak keluarga dari korban agar tindakan kekerasan tidak terulang dan berakibat fatal. Tentu hal ini dilakukan berangkat dari konsep perlindungan dalam aspek hukum Islam sebagaimana diatur dalam firman Allah surat at-Tahrim ayat 6 dan an-Nisa ayat 34 .

\section{Kesimpulan}

Berdasarkan pernyataan dan hasil temuan penelitian dapat disimpulkan sebagai berikut: sikap menutup diri dikarenakan kekerasan pada ruang lingkup rumah tangga merupakan suatu aib keluarga dan berpersepsi bahwa kekerasan yang dilakukan pelaku adalah kehilafan semata, membuat LKBH Sambas mengalami permasalahan dalam menanamkan nilai hak asasi perempuan (istri) dan nilai moral keagamaan. Namun, jika LKBH Sambas melakukan pendekatan komunikatif dan persuasif, serta menggali nilai kemaslahatan yang tertuang pada Al-Qur'an, maka akan menghasilkan kesadaran akan betapa berharganya diri seorang istri dan aktualisasi diri sebagai kebutuhan utama.

\section{Daftar Pustaka}

Ali Yafie. (1994). Menggagas Figh Sosial, cet 2. Bandung: Mizan.

Arikunto, Suhardjono, dan Supardi. (2012). Penelitian Tindakan Kelas. Jakarta: Bumi Aksara.

Azwar, Saifudin. (1988). Sikap Manusia. Yogyakarta: Liberty.

Budairi, Muhammad. (2002). Masyarakat Sipil dan Demokrasi. Jakarta: E-Law Indonesia.

Departemen Agama Republik Indonesia. (2012). Al-quran dan Terjemahannya, Cetakan Kedua. Bandung: PT. Mizan Buaya Kreativa.

Edi Suharto, (2006), "Membangun Masyarakat Membangun Rakyat. Kajian Strategis Pembangunan Sosial dan Pekerja Sosial", Rafika Aditama, Bandung

Herdiyansyah, Haris. (2012). Metode Kualitatif untuk Ilmu-Ilmu Sosial. Jakarta: Salemba Humanika.

Jim Ife. (1995). Community Development: Creatting CommunityAlternative, Vision, Analysis and Practice. Australia: Longman.

Kania, Dede. (2015). "Hak Asasi Perempuan dalam Peraturan Perundang-Undangan di Indonesia." Jurnal Konstitusi Volume 12 (Nomor 4, Desember): pp 716-734.

Margaret A, Schuler, dan Doroty Q Thomas (Penyunting). (2001). Hak Asasi Manusia Kaum Perempuan Langkah Demi Langkah. Jakarta: Pusaka Sinar Harapan.

Mudzhar, M Atho. (1998). Pendekatan Studi Islam dalam Teori dan Praktek. Yogyakarta: Pustaka Pelajar.

Nasution, Mirza. (2004). Peranan Hukum dalam Penyelesaian Masalah-Masalah Sosial. Sumatera Utara: USU digital Library.

Nofiardi. (2016). "Undang-Undang Nomor 23 Tahun 2004 Tentang KDRT Dalam Perspektif Pemikiran Hukum Islam Klasik dan Modern.” Alhurriyah: Jurnal Hukum Islam Vol. 1 No. 2 Juli-Desember.

Peraturan Daerah Kabupaten Sambas Nomor 11 tahun 2015 Tentang Penyelenggaraan Bantuan Hukum

Rahaman, M. Taufiq. (2011). Glosari Teori Sosial. Bandung: Ibnu Sina Press.

Rauf A. Hatu. (2010). "Pemberdayaan dan Pendampingan Sosial Dalam Masyarakat (Suatu Kajian Teoritis)." Jurnal INOVASI Volume 7, Nomor 4.

Saidi, Zaim. (1995). Secangkir Kopi Maxhavelar, LSM dan Kebangkitan Masyarakat. Jakarta: PT. Gramedia Pusaka Utama.

Samadani, U. Adil. (2013). Kompetensi Pengadilan Agama Terhadap Tindak Kekerasan dalam Rumah Tangga. Yogyakarta: Graha Ilmu.

Siregar, Arifin. (1992). "Sikap dan Perilaku Siswa Kelompok Etnis Keturunan Cina dalam Asimilasi

Intizar - Vol. 26 No. 2 (2020) 
Kebudayaan.” Penelitian Tesis tidak dipublikasi, Jakarta: Program Pasca Sarjana IKIP. Soekanto, Soerjono. (2007). Sosiologis: Suatu Pengantar. Jakarta: Raja Grafindo Persada.

Soeroso, Moerti Hadianti. (2010). Kekerasan Dalam Rumah Rangga Dalam Perspektif YuridisViktimologi. Jakarta: Sinar Grafika.

Undang-Undang Republik Indonesia Nomor 1 Tahun 1974 Tentang Perkawinan. 1974.

Undang-Undang Republik Indonesia Nomor 23 Tahun 2004 Tentang Penghapusan Kekerasan dalam Rumah Tangga. 2004.

Waluyo, Bambang. (2002). Penelitian Hukum Dalam Praktek. Jakarta: Sinar Grafika.

Warassih, Esmi. (2005). Pranata Hukum Sebuah Telaah Sosiologis. Semarang: Surya Alam Utama.

Wawancara dengan Dw, Ay, Pt, My, Bc, Zm, N (nama inisial korban). 2020. Istri Korban KDRT.

Wawancara dengan Landi. 2020. Pihak Sub Bidang Pidana Khusus Kepolisian Resort Sambas Terkait Kasus KDRT.

Wawancara dengan Prapto Yudono. 2020. Pihak Kepolisian Resort Sambas Terkait Kasus KDRT Di Kabupaten Sambas.

Wawancara dengan Tamrin (Ketua LKBH Sambas). 2020. Terkait dengan Peran LKBH Sambas pada Konteks Tindak KDRT.

Zuchdi, Darmiyati. (1995). "Pembentukan Sikap.” Cakrawala Pendidikan Nomor 3 Tahun XIV November.

Zulkifli. (2019. "Kekerasan Dalam Rumah Tangga Perspektif Islam.” Raheema: Jurnal Studi Gender dan Anak Volume 6 Nomor 2. 